\title{
Determinación de la velocidad de fraguado de escayolas mediante difractometría de $\mathrm{R}-\mathrm{X}$
}

\author{
Determination of setting rate in gypsum \\ casting by $X-R$ diffractometry
}

E. PERIS MORA, Dep. Ingeniería de la Construcción. Prof. Titular M. C. MILLAN, Dep. Física Aplicada. Profra. Titular Universidad Politécnica. Valencia/España

\author{
SUMMARY \\ $X$ - diffractometry is applied to evaluate the setting time of \\ gypsum pastes. A direct "observation" of the \\ crystalization phenomena, in the moment in which occurs \\ is possible using the proper radiation, in the measure of \\ the dimension what is observed. The observation is \\ developed with normal techniques and instrumentation. \\ however, areproposed some modifications in \\ diffractomete use. Is offered a new possibility in the \\ application of difractometric techniques in investigation \\ works.
}

\section{ANTECEDENTES}

La difractometría de $\mathrm{R}-\mathrm{X}$ y la microscopía electrónica son dos instrumentos esenciales en el estudio de las transformaciones del estado sólido y en particular en la interpretación de los fenómenos de fraguado y endurecimiento de conglomerantes usados en construcción como el yeso y el cemento.

Sin embargo, ambas técnicas exigen una laboriosa manipulación de la muestra a la que, además, someten durante la observación a condiciones muy especiales como irradiación, alto vacío, etc. Eso hace que normalmente se recurra a otros procedimientos menos directos pero más sencillos en alguna de las caracterizaciones más importantes de estos materiales.

Los tiempos de fraguado son una de las características de interés en yesos y cementos; la velocidad de cristalización está condicionada por el número de núcleos y su velocidad de crecimiento. El tamaño de los cristales finales, su forma y distribución granulométrica condicionan las propiedades

\section{PRECEDENTS}

$X-R$ difractometry and electron microscopy are two essential methods for the study of solid state transformations adn specially in interpretation of setting and indurating phenomena in conglomerating materials as gypsum and cement.

Though both techniques need a very complicated treatment of the sample which must be treated, during observation, under very special conditions as irradiation, high vacuum etc. That is why usually we use other methods less direct but more easier to apply in some of the more important characterizations of these materials.

The setting time is one of the most interesting characteristics in gypsums and cements; crystallization rate is conditioned by the number of nuclei and its growing velocity. The size of the final crystals, its shape, and its granulometric distribution condition the mechanical properties of the hardened 
mecánicas de las pastas endurecidas. La utilización de modificadores de fraguado acelera o retarda la cristalización y el conocimiento de los tiempos en que ésta tiene lugar es un dato de interés en muchas investigaciones.

Durante el fraguado de estos materiales se produce una reordenación de iones y moléculas de agua, lo que sucede gracias a que la propia agua actúa como vehículo a través del cual la movilidad es posible. Regourd (7) se refiere a una técnica en la que la observación de muestras húmedas mediante microscopía electrónica de transmisión es posible gracias al empleo de unas condiciones especiales entre las que se cuenta el uso de un portamuestras sellado.

En el caso particular del yeso, del que nos ocuparemos fundamentalmente, además de la norma UNE que establece el procedimiento de la aguja de Vicat como método aconsejable, existen otros procedimientos todos indirectos para valorar esa característica. Ridge \& col. (8), así como King \& col. (2) y otros, recurren a determinaciones calorimétricas; dado que la hidratación corstituye un fenómeno exotérmico la medida de las variaciones de temperatura en la hidratación del hemihidrato será señal de que la reacción está sucediendo. El fin de la reacción se detecta por la situación del máximo en la curva temperatura/tiempo. Masahiro \& col. (4), Barret (1), etc., recurren a valorar cómo varía la composición de la disolución hidratante en la que suspenden al conglomerante para de ahí deducir en qué medida los iones se habrán incorporado a la red cristalina que se está formando en cada instante. En otras ocasiones, como hacen Lane y Summerfield (3), se preparan simultáneamente varias probetas cuya hidratación se irá interrumpiendo en diferentes intervalos para de esa forma interpretar el proceso de cristalización en su conjunto. Moissey (5) se refiere a los métodos tradicionales y cita, además, las técnicas de variación de la conductividad como procedimiento de evaluación de la velocidad de fraguado.

\section{OBJETIVOS}

En el presente trabajo se estudia la posibilidad de aplicar técnicas de difractometría de rayos $X$ para evaluar los tiempos de fraguado de pastas de yeso (escayolas). Se trata así de proporcionar un método de "observación" directa del fenómeno de cristalización en el momento en que se está produciendo la hidratación del hemihidrato; la observación se realiza mediante el uso de la radiación adecuada, products. The utilization of forging modifiers, accelerate or retard crystallization and the knowledge of time in which cristallization takes place are interesting in many investigations.

During forging of these materials, ions and watermolecules suffer a reordenation because water itself is a vehicle in which mobility is possible. Regourd (7) talks about a technique in which the observation of wet samples by electron microscopy of transmission is possible due to very special conditions used, and between them, the use of a sealed sample holder.

In the particular case of gypsum, which we study fundamentally, beyond the UNE norm establishes the proceeding of the Vicat needle like a recommended method, exist other procedures all of them not direct, to value that characteristique. Rigge and col. (8). King and col. (2) and others resort to calorimetric determinations; so that hydratation is an exothermic phenomena the measure of hemihydrate temperature variations is a test that the reaction is occuring. The end of the reaction is detected by the situation of the maximum in the plot temperature/time. (Masahiro and col. (4); Barret (1), etc., resort to study the variation in composition of the hydratating dissolution in which the conglomerating material is suspended, to deduce in which proportion ions are incorporated to the lattice that is growing in every instant. In other cases [Lane and Summerfield (3)] several samples are prepared simultaneously an their hydratation will be interrupting in different time intervals to interprete the process of the global crystallization Moissey (5) talks about traditiona methods and names, moreover, the techniques of variation of conductivity as a procedure of evaluation o forging velocity.

\section{OBJETIVES}

In the present work, we study the possibility of apply $X-R$ diffractometric tecniques to value times of forging of gypsum pastes. We try to develop a method of "direct" observation of the crystallization phenomena, in the moment in which hydratation of the hem hydrate occurs: the observation is possible using the proper radiation, in the measure of the dimensions of what we observe. Normal techniques and instrumentation are used. 
acorde con la dimensión de lo observado. Se utilizan técnicas e instrumentación normales, si bien se proponen algunas modificaciones que los hagan válidos para la observación propuesta. Sin embargo, no se trata de proporcionar un sistema de uso generalizable que sustituya a los sistemas sencillos de evaluación en obra (Vicat, cuchillo, etc.) sino más bien de aportar una nueva posibilidad de aplicación de las difractometrías en trabajos de investigación, en el laboratorio.

\section{MATERIAL Y METODOS}

Se ha utilizado un difractómetro de rayos $X$ Philips PW-1130, provisto de tubo de rayos $X$ con anticátodo de $\mathrm{Cu}$, y filtro de $\mathrm{Ni}$, con lo que prácticamente se emplea sólo la radiación $\mathrm{Ka}$ $(\lambda=1.542 \mathrm{~A})$ y detector de centelleo.

Condiciones de trabajo de $20 \mathrm{~mA}$ y $40 \mathrm{KV}$.

La técnica tradicional de la DRX consiste en la obtención de una gráfica difracción/ángulo en el intervalo angular que se considere más carácterístico del sólido estudiado.

En el caso de una sustancia como el $\mathrm{CaSO}_{4}$, que en la hidratación del yeso, pasa en pocos minutos de la forma $1 / 2 \mathrm{H}_{2} \mathrm{O} . \mathrm{CaSO}_{4}$ a la forma $2 \mathrm{H}_{2} \mathrm{O}$. $\mathrm{CaSO}_{4}$, lo diferentes difractogramas, de producirse reiteradamente durante la hidratación, proporcionarían una "película" del desarrollo del proceso.

Sin embargo, puesto que el barrido angular completo dura, en general, varios minutos, no será práctico observar la totalidad de los picos representativos sino que, para nuestro objetivo - controlar la velocidad de fraguado- es suficiente tomar como referencia alguno de los máximos representativos diferenciadores entre ambas formas hidratadas. De esta manera, realizando una difractometría señal/tiempo (a ángulo fijo) se obtendrá información adecuada sobre el desarrollo del proceso de hidratación.

Con estos criterios, en unos ensayos tentativos realizados en primer lugar se consideró que como índice de la hidratación se debiera escoger uno de los picos de difracción presentes en la gráfica del dihidrato pero inexistente en la forma hemihidrato; la aparición de la señal de difracción, al someter a la muestra a una radiación bajo ángulo adecuado, sería señal de la presencia de los cristales dihidratados. Despúes de reiterados intentos se desechó este procedimiento y en su lugar se eligió el alternativo, es decir: elegir un máximo presente en la forma menos hidratada y ausente en la otra, de manera que la desaparición de la señal indicaría la however, we propose some modification, to make them usefull for the propased observation. Although, we don't try to develop a general system to substitute simple systems of evaluations over work (Vicat, knife, etc.). We try, however to estabish a new possibility in the application of diffractometric techniques in investigation works, in the laboratory.

\section{MATERIAL AND METHODS}

We have used a $X-R$ diffractometer Philips $P W-1130$, provided with and $X-R$ tube with anticathode of and a Ni filter, so that we practically only use the radiation $\mathrm{Ka} \mathrm{Cu}$ $(\lambda=1.542 \AA)$ and a flashing detector.

The conditions of work are $20 \mathrm{~mA}$ and $40 \mathrm{kV}$.

The traditional technique of $X R D$, consists in obtain a plot diffraction/angle in the most charateristic angular interval of the materials in study.

In the case of a substance as $\mathrm{CaSO}_{4}$, that in hydratation of gypsun changes in few minutes from the form 1/2 $\mathrm{H}_{2} \mathrm{O}$. $\mathrm{CaSO}_{4}$ to the form $2 \mathrm{H}_{2} \mathrm{O} . \mathrm{CaSO}_{4}$, different diffractograms produced one after the other, during the hydratation provide a "film" of the development of the process.

However, since the complete angular sweep lasts in general, some minutes it won't be very usefful to observe all the representative peaks, but for our objetive to -control the velocity of forging - it is enough to take as a reference one of the representative peaks differentiators between both hydrated forms. In this way, making a signal/time diffractometry in a fixed angle, we will obtain the right information about the development of the hydratation process.

With these criteria, in one of the preliminary purposes we considered as on hydratation index should choose one of the diffraction peaks present in the plot of the dihydrate but not in the form of hemihydrate. The apparition of the diffraction signal, when we put the sample under radration in a desired angle, is a test of the existence of dihydrate crystals. After many attempts, we excluded this proceeding and we chose the alternative, this means: we chose a maximum present in the less hydrated form that did not exist in the other, so that the disappearance of the signal would be an index of hydratation. This decision is justified by the fact, that we start and existing signal in a fised 
hidratación. La decisión se justifica en el hecho de que cuando se parte de una señal existente en un determinado ángulo su desaparición es segura, mientras que al elegir un ángulo en el que se espera aparezca el pico de la forma hidratada, no siempre se acertará (por pequeñas variaciones del ángulo de incidencia sobre la muestra) en aquél en el que la difracción va a producir el máximo de señal.

Las experiencias realizadas se desarrollaron de acuerdo con la siguiente secuencia:

A) Difractometría de barrido de las muestras de hemihidrato y dihidrato, en el intervalo de ángulos 10-32 grados que es donde aparecen los picos más representativos $\mathrm{I} / \mathrm{I}_{0}>0.5$. Con el criterio justificado más arriba se eligió el pico correspondiente al ángulo de 11.58 grados.

B) Elección del procedimiento de preparación de muestra y de la relación agua/yeso. Para lo cual se ensayaron diferentes procedimientos de amasado con objeto de elegir el que ofreciera mejores condiciones de reproducibilidad, contando con los recursos sencillos con los que hemos contado en estas experimentaciones. Se adopta el siguiente procedimiento: "en una cápsula de vidrio de fondo redondo se ponen 10 gramos de yeso sobre los que se vierte la cantidad elegida de agua, medida con pipeta graduada; se amasa con espátula cuidadosamente de manera que desaparezcan todos los grumos; previamente se habrá preparado el portamuestras de la difracción cubriéndolo por la parte de abajo (la no irradiada) con un rectángulo de papel de filtro sujeto con cinta adhesiva; en el recipiente que constituye el portamuestras así preparado se extiende con la misma espátula de amasado la cantidad de pasta necesaria, aplanando la superficie a irradiar".

La relación agua/yeso se escogió de 0.7 y el tiempo de amasado-colocación en 1 minuto, tras varias pruebas y considerando que una mezcla más seca limitaría las posibilidades de empleo de aceleradores de fraguado en ensayos posteriores. El empleo de papel de filtro como base del recipiente portamuestra se justifica porque se ha observado que de esa forma, además de aislar del contacto del papel adhesivo habitualmente utilizado, constituye una reserva de humedad y mejora la aplicabilidad de la pasta. El material utilizado en todos los ensayos es yeso (variedad escayola) cuyas características químicas eran conocidas por haber sido determinadas en un trabajo anterior (6). angle, its disappearance is sure, while if we choose an angle in wich a signal must appear we won't always hit by small variations in the incidence angle over the sample) in that sample in wich the dyffraction will produce maximum of the signal.

The experiences were developed keeping the following sequence:

A) Sweeping diffractometry in samples of hemihydrate and dihydrate, in an angle intervale of 10-32 degrees which is where more representative peaks appear $\left(I / I_{0}>0,5\right)$, with the previous criteria justified, we chose the corresponding peak that appears at an angle of 11,58 degrees.

B) Choice of the procedure of preparation of the sample and the water/gypsum ratio. We tried different proceedings of kneading in order to choose the one that offers the best reproducibility conditions, working with the simples techniques that we had for these experimentations. We worked in the following way: "in a glass hemyspheric bowl we put 10 grams of gypsum and the chosen quantity of water over them, measured with a graduated pipette; we knead with a spatula very carefully to make grumes disappear; sample-previously, we have prepared the diffraction holder covering it on the bottom side (the one that is not irradiated) with rectangular filter paper, held with an adhesive strip, in the container that constitutes the sampleholder, we spread with the same spatula of kneading, the necessary quantity of gypsum paste, and we flatten the surface that is going to be irradiated".

We chose a water/gypsum ratio of 0,7 and the time of kneading-setting in one minute, after some trials and cosidering that a drier mixture would limit the possibilities of use of forging accelerators in later experiments. The use of filter paper as a base of the sample-container is due to the fact that we observer that in this way, besides isolate the contact with adhesive paper that is often used, it constitutes an humidity reservoir and it improves the applicabylity of the paste. The material used in all our experiments is gypsum (casting variety) of which chemical proprieties were known because they were determined in a previous work (6). 
C) Por último, elegidas las condiciones de amasado y preparación de muestra se desarrollan los difractogramas señal/tiempo con la siguiente metodología:

"Elegidas las condiciones instrumentales, tras la realización de algunas pruebas tentativas, se coloca la pasta de ensayo en el portamuestras del aparato y se inicia la difracción. Al principio se ajusta el ángulo de incidencia en los 11.58 grados, que se modifican ligeramente mediante tanteo sobre el nonius del aparato, hasta que la señal registrada corresponda prácticamente al máximo. En esas condiciones se deja desarrollar el difractograma hasta que, después de descender, se alcanza la linea de base. El fin del fraguado se obtiene mediante determinación gráfica en el punto en el que se alcanzó por primera vez el valor mínimo (ver figuras).

En estas condiciones se han desarrollado diferentes difractogramas usando el ión $\mathrm{Cl}^{-}$ como acelerador a diferentes concentraciones, según se indica en el pie de las figuras.

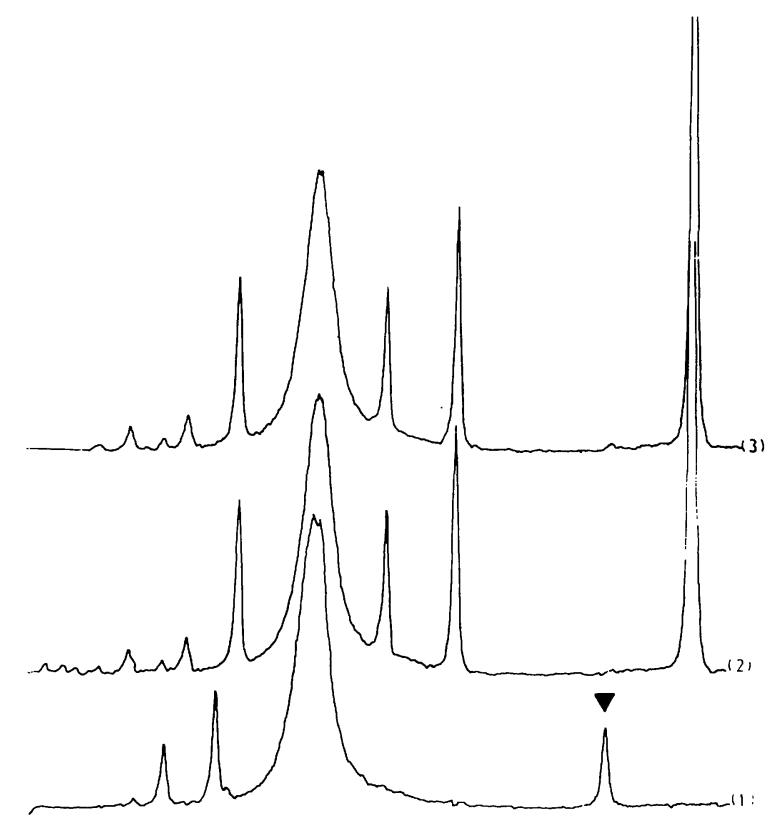

Fig. 1.-Las gráficas corresponden a los difractogramas de barrido señal/ángulo de diferentes muestras: (1) Hemihidrato cálcico en forma de polvo seco; (2) Pasta amasada una hora después de la adición de agua, por lo tanto dihidrato; (3) La misma anterior 24 horas más tarde. El proceso de hidratación, de acuerdo con los difractogramas, ha alcanzado el total de transformación antes de 1 hora.

Fig. 1.-This plot correspond to the sweep diffractogram signal angle in the sample: (1) hemihydrate calcio in form of dry dust; (2) Kneaded paste, one hour after addition of water, so dihydrate: (3) the same before, after 24 hours. The hydratation process, according to diffractograms, has reached the whole transformation in a time under one hour.
C) Finally, once we chose the kneading and preparing of the sample conditons, we make the diffractograms signal/time with the following methodology:

"Once we chose the instrumental conditions, after made some tentative experiments, we set the trial paste over the sample-holder of the apparatus and we start the diffraction. At the beginning, we adjust the incidence ang in 11,5 degrees, that are slighty modified by tentative over the nonius of the apparatus, until the motions registered signal corresponds to the maximum. Under these conditions we the diffractogram be made until, after a lowering, we reach the base-line. The end of forging is obtained by graphic determinination in the first point where appears the minimum value (see plot).

In these conditions we have developed different diffactograms by using the Cl-ion as an accelerator in different concentrations, as we explain in the diagrams.

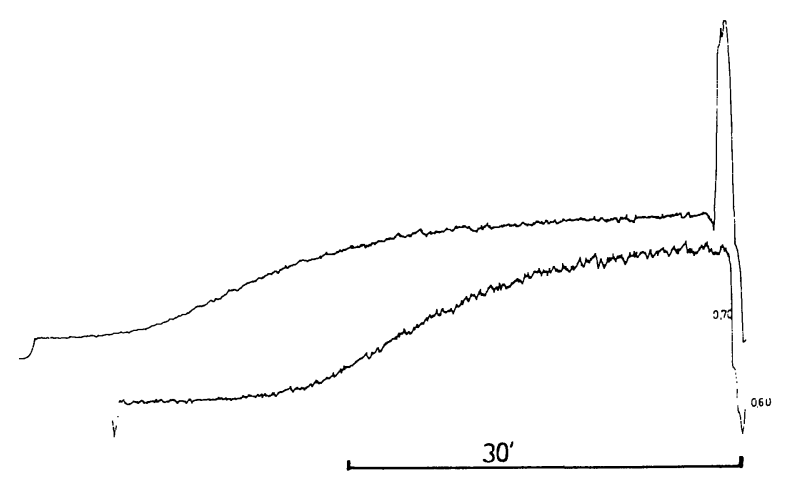

Fig. 2.- La relación agua/escayola se elige de 0.7. Un amasado más seco produce un fraguado más rápido, como se ve por las curvas de la gráfica correspondiente a las relaciones 0.6 y 0.7

Fig. 2.-The water/gypsum ratio chosen is 0,7. A drier kneading produces a faster forging, as we can see in the curves of the corresponding plot in ratio of 0,6 and $0, i$ 


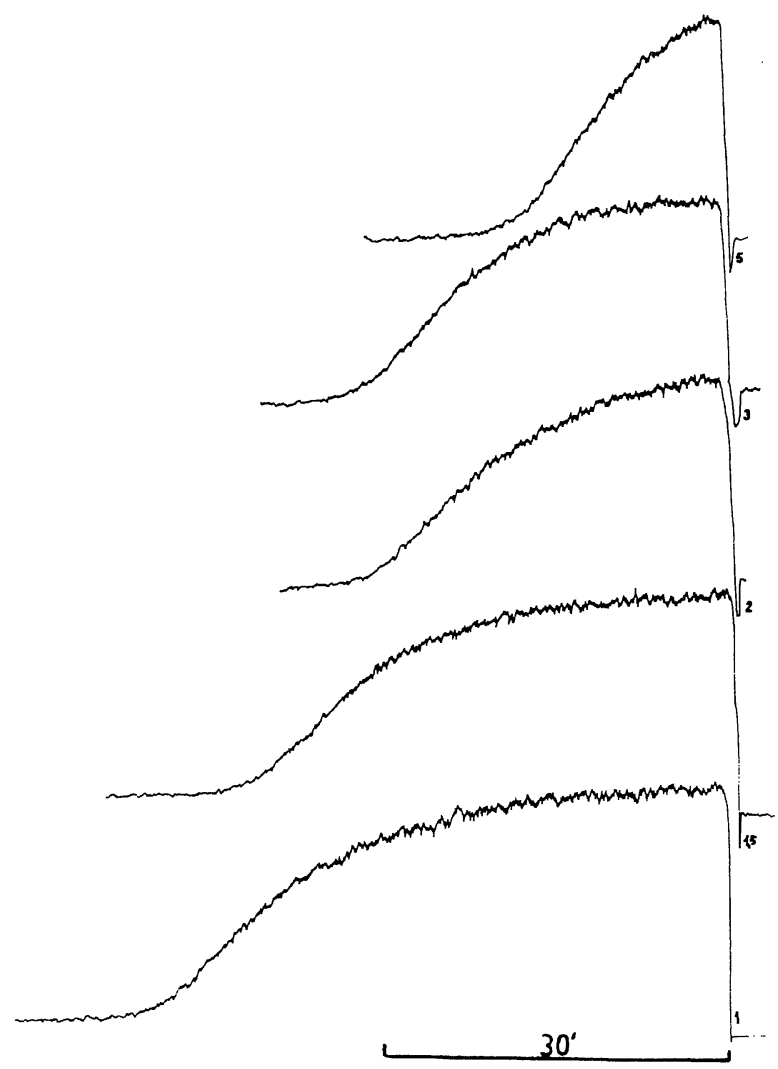

Fig. 3.-El tiempo de amasado se elige tras realizar algunas experiencias tentativas. En la gráfica se representan las gráficas para determinar los tiempos de fraguado (que corresponden con las abscisas del principio del tramo horizontal de cada curva) de muestras amasadas durante: 1 minuto; 1.5 minutos; 2 minutos; 3 minutos; 5 minutos. Todas ellas se realizaron con amasado relación agua/escayola $=0.7$.

Fig. 3.-Kneading time is chosen after we realize some tentative experiences. In the plot, we represent forging times (that is the horizontal axis) of kneaded samples during 1 minute, 1,5 minutes; 2; 3 ; and 5 minutes. All of them were realized with a kneading ratio of water/gypsum $=0,7$.

\section{RESULTADOS Y DISCUSION}

Las técnicas aplicadas no hacen sino modificar las habituales en las difractometrías de rayos $X$ en el sentido de que en estas circunstancias lo importante no es identificar la muestra de partida, que se supone suficientemente caracterizada mineralógicainente, sino descubrir la aparición de una nueva especie química, el dihidrato, y el tiempo que transcurre hasta que éste termina de suceder. Si usualmente el barrido permite recorrer todos los ángulos en que aparecen difracciones características, en nuestro caso se trata solo de seguir la variación de intensidad del pico elegido como más representativo.

La primera objeción que se podría hacer al procedimiento es la posible modificación del fenómeno que pudiera darse por la incidencia

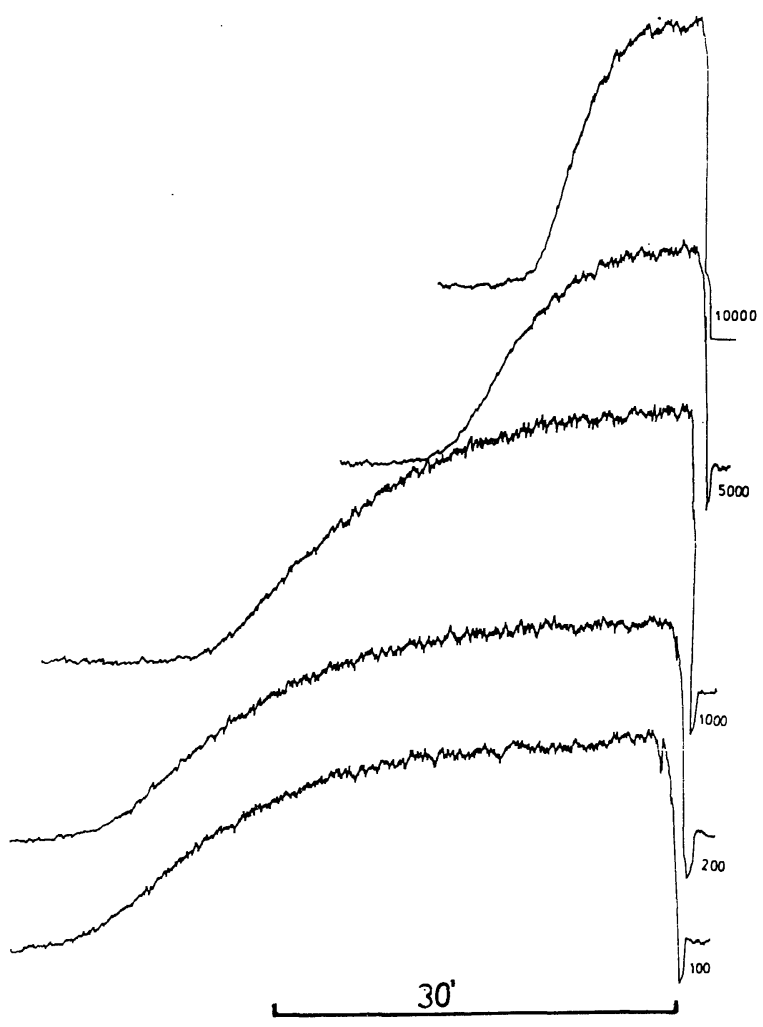

Fig. 4.-El carácter del $\mathrm{Cl}$ como acelerante del fraguado se manifiesta en las gráficas de esta figura, en donde se han amasado durante 1 minuto y con relación agua/escayola $=0.7$. Las cinco muestras corresponden con agua de amasado con concentraciones de $\mathrm{Cl}$ de: 100 ppm; 200 ppm; 1.000 ppm; 5.000; 10.000 ppm.

Fig. 4.-The accelerating proprieties in forging, of $\mathrm{Cl}$ ion, is observed in this plot where we kneaded, during one minute, and with a ratio water/gypsum $=0,7$, five samples with $\mathrm{Cl}$ concentration, of: 100 ppm; 200 ppm; 1.000 ppm; $5.000 \mathrm{ppm}$; and $10.000 \mathrm{ppm}$.

\section{RESULTS AND DISCUSSION}

The techniques used merely modify the usual techniques in X-R diffractometries in the sense that in these circunstances is not important to identify the starting sample, that is supossed to be very well characterized mineralogically, but to find out the presence of a new chemical substance, the dihydrate and the time that takes untill it appears completely. If the angle-sweep usually permits us to see all the angles in wich diffraction appears, in our case we only study the variation of intensity of the peak chosen as more representative.

The first objection that we could make for this proceeding is the possible modification of the phenomena that could arise due to it taking 
del haz de rayos $X$ pues éste podría perturbar la propia reacción de hidratación. En las condiciones en que se realizaron nuestras experiencias se comprobó como era de esperar (9), mediante la inclusión de un termopar en dos probetas con y sin irradiación, que no aparecían diferencias significativas de temperatura entre las dos situaciones.

La determinación del tiempo correspondiente al "fin de fraguado" se realiza por extrapolación gráfica de la asíntota lo que proporciona resultados suficientemente precisos. En algunos casos se presentan diferencias de ordenada máxima entre muestras idénticas consecutivas, lo que no interpretamos; nos limitamos a sugerir posibles causas como son: deriva de la línea de base del aparato, diferencias en la superficie de la muestra por aplicación de la pasta con espátula, etc.

La hidratación de pastas de cemento sería posible utilizando los mismos procedimientos, si bien, debido a que en ese material las recristalizaciones son mucho más lentas, incluso en el período de final de fraguado sería necesario mantener en funcionamiento ininterrumpido el aparato, lo que resulta un inconveniente por el prolongado trabajo al que se le somete, al mismo tiempo que las posibles derivas de la línea de base podrian desvirtuar los resultados.

\section{CONCLUSION}

La utilización de la difracción de rayos $X$ para observar procesos de fraguado es posible en yesos en donde los procesos de hidratación tienen lugar en tiempos relativamente cortos; en ellos es posible determinar con suficiente precisión los tiempos reales de fraguado así como, cuidando adecuadamente la preparación de las muestras, realizar valoraciones de las diferentes variables que condicionan los tiempos de fraguado, como son granulometrias, aceleradores o retardadores, etc. Si bien no se sustituye a lo procedimientos tradicionales más sencillos y baratos, el procedimiento puede constituir, a nuestro juicio, un método valioso en trabajos de investigación. place under the incidence of the $X-R$ radiation, and this radiation may perturb our experiences, we found out, as we spected, by inclusion of a thermopar in two test-samples, with and without radiation that no significante difference appears between both situations.

The determination corresponding to the "end of forging" is realized by graphic extrapolation of the asymptote so that we can obtain quite exact results. In some cases, we obtain different possitions of the chosen maximum between identical samples, what we don't interpret we suggest some possible reasons as: deviation of the base-line in the apparatus, difference in the sample surfaces by application of the paste with the spatula, etc.

The hydratation of cement pastes would be feasible, by using the same proceedings, though, due to the recrystallization being much lower, even in the last forging period of this material it would be necessary to keep the apparatus working, that is an inconvenient due to the long work that it is submitted to, and furthermore the possible deviations of the base-line could alter results.

\section{CONCLUSSION}

The use of $X-R$ diffraction to study forging processes, is possible in those gypsums in which hydratation process takes place in a relative short time; in them, is possible to find out with eneugh exactness real forging time and, taking care of the different variables that condition forging time, as granulometries, existence of accelerators or retardedors, etc. Though we dont try to substitute the traditional procedures that are easier to apply and cheaper, we think which procedure may be a valuable method in research.

\section{BIBLIOGRAFIA}

(1) BARRET, P.: Modelisation et reactivité des materiaux. Ciments, Betons, Platres, Chaux. N. 755-4/1985.

(2) KING, G. A.; RIDGE, M. J.; WALTER, G. S.: The hydration of Calcium Sulphate Hemihydrate: Some new aspects. J. Appl. Chem. Biotechnol. Vol. 28. 353-365. 1978.

(3) LANE, M. K.; SUMMERFIELD, J. M.: Effect of Particle Size of Plaster on Strength Development of Foamed Casts. Ceramic Bulletin. Vol. 54, N. 3, pp. 291-295. 
(4) MASAHIRO, K.; SHEEHAN, M. E.; NANCOLLAS, G. H.: The Crystal Growth of Gypsum in Ammoniacal Environment. J. Inorg. Chem. Vol. 43 pp. 917-920. 1981

(5) MOISSEY, J. M.: Modificateurs de Prise des Platres. Ciments, Betons, Platres, Chaux, n. 758-5/1985.

(6) PERIS MORA, E.; MILLAN, M. C.; BONILLA, M.: Comparación del Comportamiento de dos Escayolas Amasadas con Aguas Contaminadas. Materiales de Construcción, octubre/diciembre 1987. (7) REGOURD, M.: Microstructures et propietés des Ciments, Mortiers et Bétons. Ciments, Betons, Platres, Chaux.
N.734-1/1982.

(8) RIDGE, M. J.; SURKEVICIUS, H.; LARDNER, K. I.: Hydration of Calcium Sulphate Hemihydrate. II Acceleration by Neutral Salts. J. Appl. Chem. N. 12. June. 1962.

(9) RUDMAN, R.: Low-Temperature X-R Diffraction. Plenum Press N.Y. 1976.

\section{publicaciones del i.e.t.c.c.}

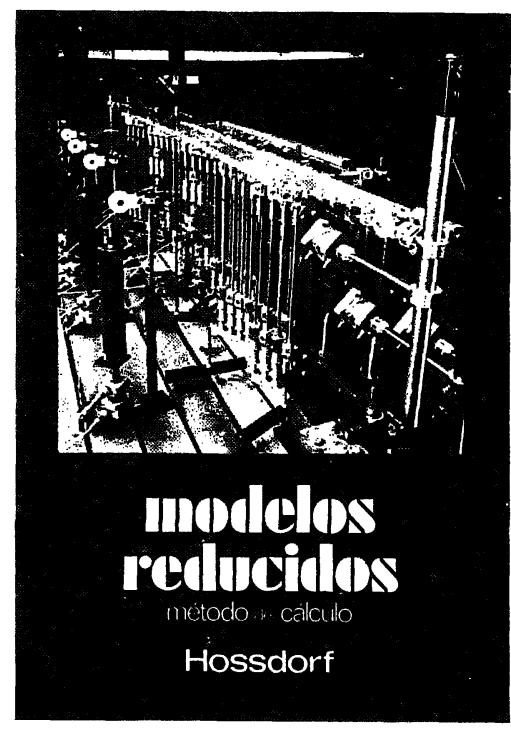

Modelos reducidos. Método de cálculo

H. Hossdorf, Ingeniero Civil

La técnica de los ensayos en modelos reducidos de estructuras sufre hoy dia una decisiva metamorfosis. Hasta hace poco era un medio más bien de artesania, que no siempre era tomado en serio por los miento resistente de las estructuras complejas y a que se acudió las más de las veces, como a un último remedio debido a sus indiscutibles insuficiencias. Sin embargo, en poco tiempo y gracias a su conexión con los ordenadores digitales, se ha transformado en un instrumento cientificamente valioso, que no puede quedar a un lado en la práctica diaria del Ingeniero Proyectista.

Un volumen encuadernado en cartoné plastificado con lomo de tela, de $17 \times 24 \mathrm{~cm}$, compuesto de 250 páginas, 158 figuras y fotografias.

Precios: 1.800 ptas.; \$ USA 26.00

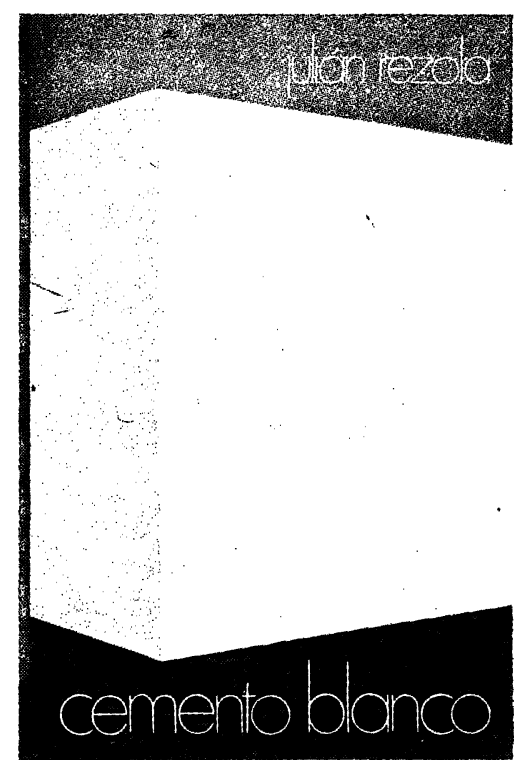

\section{Cemento blanco}

Julián Rezola

Ingeniero Quimico Dipl I. O. S.

Sabido es que existe una extensa y documentada bibliografia sobre el cemento gris: en cambio, no puede decirse lo mismo acerca del cemento portland solo a algunas peculiaridades que le distinguen de aquél.

El autor nos ofrece sus profundos conocimientos y su larga experiencia tanto en laboratorio como en fabricación.

La parte descriptiva del libro se complementa con gráficos, diagramas y fotografias de gran utilidad, a conseguir la aplicación apropiada de este aglomerante.

Un volumen encuadernado en cartoné policerado, de $17,4 \times 24,3 \mathrm{~cm}$, compuesto de 395 páginas, numerosas figuras, tablas y ábacos.

Precios: España, 1.700 ptas.; extranjero, $\$ 24.00$

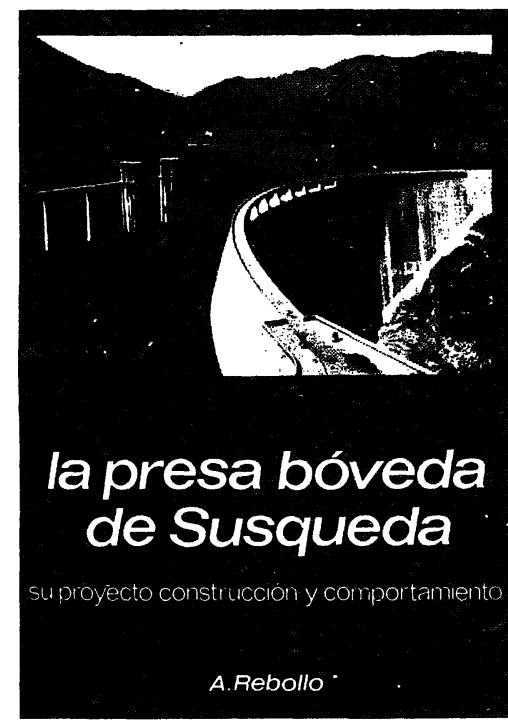

La presa bóveda de Susqueda

A. Rebollo,

Dr. Ingeniero de Caminos

El esfuerzo del constructor de presas se sitúa, por su pretensión de perennidad, a contracorriente de las tencias de la civilización actual, caracteizada por lo fungible. Pueden evocarse las 10.000 grandes.presas en funcionamiento o en construcción que gerontologicos para ma $y$ recla $y$ peffeccionar su perennid obras, grandes 0 pequeñas, son portadoras riesgos ecológicos $y$ a veces, catastróficos, que aumentan con el envejecimiento, la gerontologia de las presas es todo un emplazo. La acción adelantada de Arturo Rebollo en este terreno marca un camino a seguir para todos los que aman su propia obra con la devoción paternal que él ha puesto en Susqueda.

Un volumen encuadernado en cartoné plastificado con lomo de tela, de $18 \times 24,5 \mathrm{~cm}$, compuesto de 408 páginas, 330 figuras $y$ fotografias y 39 tablas. Precios: 1.700 ptas.; extranjero, \$ USA 24.00. 